\title{
PENGEMBANGAN LABORATORIUM VIRTUAL BERBASIS WEBSITE DI KELAS X TEKNIK KOMPUTER DAN JARINGAN (TKJ)
}

\author{
Dara Riska*, Afrizal Mayub, Rosane Medriati \\ Program Studi S1Pedidikan Fisika FKIP-UNIB \\ Jalan. W.R Supratman Kandang Limun, Bengkulu \\ e-mail*: darariska29@gmail.com
}

\begin{tabular}{c|c|c}
\hline Diterima 19 Juli 2020 & Disetujui 29 Desember 2021 & Dipublikasikan 14 Januari 2022 \\
\hline \multicolumn{3}{|c|}{ https://doi.org/10.33369/jkf.4.3.193-202 } \\
\hline
\end{tabular}

\begin{abstract}
ABSTRAK
Penelitian ini bertujuan untuk mendeskripsikan pengembangkan dan kelayakan media pembelajaran laboratorium virtual berbasis website pada materi suhu dan kalor kelas X TKJ SMKN 3 Kota Bengkulu. Penelitian ini merupakan penelitian dan pengembangan ( $R \& D$ ) dengan metode 4D namun hanya sampai pada tahap 3D. Proses pengembangan terdiri dari tahap pendefinisian atau define, perancangan atau design, dan pengembangan atau develop. Hasil validasi menunjukkan bahwa media pembelajaran laboratorium virtual berbasis website ini dikategorikan sangat layak digunakan dengan kriteria $87,5 \%$. Persentase tersebut merupakan rata-rata dari aspek format $=85,41 \%$ dengan kriteria sangat layak; aspek ilustrasi $=86,1 \%$ dengan kriteria sangat layak; aspek bahasa $=85,41 \%$ dengan kriteria sangat layak; dan aspek isi $=91,67 \%$ dengan kriteria sangat layak. Dengan demikian dapat disimpulkan bahwa media pembelajaran laboratorium virtual berbasis website pada materi suhu dan kalor memenuhi kriteria dengan kualitas sangat layak sebagai salah satu media pembelajaran yang digunakan peserta didik kelas X SMKN 3 Kota Bengkulu.
\end{abstract}

Kata kunci: Pengembangan, laboratorium virtual, website, suhu dan kalor

\begin{abstract}
The purpose of this research was to described development and appropriateness of virtual laboratory learning method based on website on temperature and heat theory class X TKJ SMKN 3 Kota Bengkulu. This research was research and developing ( $R$ \& D ) with 4D method has been modified to 3D. Development process consist of definiton phase or define, design phase or design, and development or develope. Validation result indicated this virtual laboratory learning method based on website categorized very appropriate to use with criteria $87,5 \%$. That percentage was average from format aspect $=85,41 \%$ with criteria very appropriate; illustration aspect $=86,1 \%$ with criteria very appropriate; language aspect $=85,41 \%$ with criteria very appropriate; and content aspect $=91,67 \%$ with criteria very appropriate. Therefore can be concluded that virtual laboratory learning method based on website on temperature and heat theory fulfilled the criteria with very appropriate qualityas one of the learning method used by student class X TKJ SMKN 3 Kota Bengkulu.
\end{abstract}

Keyword: Development, virtual laboratories, websites, temperature and heat

\section{PENDAHULUAN}

Fisika berasal dari kata physics artinya ilmu alam, yaitu ilmu yang mempelajari tentang alam. Peristiwa-peristiwa yang sering terjadi seperti apel yang jatuh, kenapa pesawat bisa terbang, kenapa gitar bisa menggeluarkan bunyi, dan lain sebagainya menyebabkan pemikiran tentang fisika tercipta. Kegiatan pembelajaran fisika lebih ditekankan pada pemberian pengalaman belajar langsung kepada peserta didik, guru sebagai fasilitator dan peserta didik aktif dalam proses pembelajaran (1).

Fisika sebagai bagian dari Ilmu Pengetahuan Alam (IPA) merupakan salah satu kajian bidang ilmu yang mempelajari peristiwa dan gejala-gejala yang terjadi di alam semesta, yang pada hakikatnya meliputi empat unsur utama yaitu: a) sikap: rasa ingin tahu tentang benda, fenomena alam, makhluk hidup, serta hubungan sebab akibat yang menimbulkan masalah baru yang dapat dipecahkan melalui prosedur yang benar; b) proses: prosedur pemecahan masalah melalui metode 
ilmiah yang meliputi penyusunan hipotesis, perancangan eksperimen atau percobaan, evaluasi, pengukuran, dan penarikan kesimpulan; c) produk: berupa fakta, prinsip, teori dan hukum; dan d) aplikasi: penerapan metode ilmiah dan konsep IPA dalam kehidupan sehari-hari (2).

Fisika di sekolah membuat peserta didik terkadang sulit untuk memahami konsep fisika. Sehingga dalam proses belajar-mengajar perlu adanya media pembelajaran yang dapat membantu guru dalam menjelaskan materi fisika kepada peserta didik(3). Menurut Hamalik tentang media pembelajaran bahwa pemakaian media pembelajaran dalam proses belajar mengajar dapat membangkitkan keinginan dan minat yang baru, membangkitkan motivasi dan rangsangan belajar, dan bahkan membawa pengaruh-pengaruh psikologis terhadap peserta didik. Belajar dengan disertai minat dan motivasi yang tinggi maka akan lebih memudah peserta didik dalam memahami materi yang sedang dipelajari. Oleh karena itu diperlukan inovasi media pembelajaran yang sesuai dengan perkembangan teknologi dunia ini yakni media pembelajaran yang lebih menarik untuk dipelajari, lebih mudah dipahami dan lebih leluasa dalam pemakaiannya dimana pun dan kapan pun (4).

Istilah media berasal dari bahasa latin yang merupakan bentuk jamak dari "medium" yang secara harfiah berarti perantara atau pengantar (5). Menurut Gagne dan Briggs media pembelajaran meliputi alat yang digunakan untuk menyampaikan isi materi pengajaran seperti buku, film, slide, dan gambar (6).

Praktikum merupakan cara terbaik dalam mempelajari IPA terkhusus fisika. Kegiatan yang dilakukan pada praktikum melalui eksperimen dapat menemukan sebuah konsep fisika. Sehingga dalam pembelajaran fisika diperlukan kegiatan praktikum. Ada beberapa alasan tentang pentingnya dalam melakukan kegiatan praktikum. Yang pertama adalah, praktikum membangkitkan motivasi belajar IPA. Yang kedua adalah, melakukan praktikum untuk mengembangkan keterampilanketerampilan dasar melalui eksperimen. Yang ketiga adalah, praktikum menjadi wadah belajar dengan pendekatan secara ilmiah. Yang keempat atau terakhir, praktikum dapat menunjang materi pembelajaran di $\operatorname{sekolah}(7)$.

Dibalik banyaknya manfaat dari praktikum, diperlukannya alat dan ruangan praktikum yang memadai untuk melaksanakan praktikum. Namun hal ini bertolak belakang dengan kondisi beberapa sekolah di Indonesia. Masih banyak sekolah yang tidak memiliki ruang laboratorium ataupun alat yang tersedia tidak lengkap menyebabkan praktikum sulit dilaksanakan di sekolah. Laboratorium (disingkat lab) adalah tempat riset ilmiah, eksperimen pengukuran ataupun pelatihan ilmiah dilakukan. Laboratorium biasanya dibuat untuk memungkinkan dilakukannya kegiatankegiatan tersebut secara terkendali. Sehingga perlu media untuk membantu dalam melaksanakan kegiatan praktikum. Solusi agar praktikum tetap terlaksana walaupun tidak secara langsung atau sebagai alternatif praktikum riil adalah dengan cara melaksanakan kegiatan praktikum secara $\operatorname{virtual}(8)$.

Adapun kelebihan praktikum riil, yaitu membuat peserta didik lebih percaya atas kesimpulan berdasarkan percobaan, membina peserta didik untuk membuat terobosan-terobosan baru dengan penemuan dari hasil percobaannya dan bermanfaat bagi kehidupan manusia, hasil-hasil percobaan yang berharga dapat dimanfaatkan untuk kemakmuran. Sedangkan kelemahan praktikum ini antara lain, memerlukan alat dan bahan yang tidak selalu mudah dan murah, menuntut ketelitian, keuletan, dan ketabahan, setiap percobaan tidak selalu memberikan hasil yang diharapkan, dan ketidakamanan di laboratorium karena bahan tertentu yang berbahaya, terbatasnya waktu untuk mempersiapkan dan melakukan kegiatan praktikum (9).

Praktikum virtual merupakan suatu kegiatan dalam lingkup laboratorium yang disajikan dalam bentuk digital di dalam komputer. Praktikum virtual ini juga membutuhkan suatu laboratorium yang juga bersifat virtual, atau dalam hal ini biasa disebut dengan laboratorium virtual. Laboratorium virtual yang merupakan simulasi komputer ini digunakan karena konsep pembelajaran Fisika paling baik dipelajari melalui investigasi melalui eksplorasi secara langsung penggunanya (10).

Berkembangnya Teknologi dan Informasi (IT) yang pesat saat ini dapat mempengaruhi penggunaan IT sendiri untuk kebutuhan konsep dan proses pembelajaran di sekolah. Semua golongan tanpa mengenal usia dan latar belakang seakan terpaksa mengenal internet, terutama peserta didik di sekolah. Peran internet saat ini sangat penting, sehingga internet tidak pernah lepas 
di kehidupan sehari-hari. Teknologi menuntut setiap elemen di sekolah menggunakan internet agar tidak ketinggalan dalam mendapatkan informasi. Selain melalui buku, informasi bisa kita dapatkan dengan mudah melalui internet. Maka diperlukan pemanfaatan internet sebagai media pembelajaran dari sistem e-learning, sebagai contohnya yaitu penggunaan website. Website dapat menghasilkan gambar, animasi, suara, dan lainnya baik yang bergerak ataupun diam. Oleh karena itu website dapat berperan dalam proses pembelajaran (11).

Hal ini sangat menunjang pembelajaran fisika di jurusan Teknik Komputer dan Jaringan (TKJ) yang mana mereka berada di ruang lingkup yang cocok untuk menjalani laboratorium virtual. Peserta didik tidak pernah lepas dari perangkat komputer dalam kesehariannya. Sehingga peserta didik hanya memfokuskan diri terhadap mata pelajaran yang berhubungan dengan jurusannya. Di SMK ada 3 macam mata pelajaran, yaitu mata pelajaran produktif, mata pelajaran normatif, dan mata pelajaran adaptif. Mata pelajaran produktif berhubungan dengan program keahlian atau kejuruan yang dipilihnya, mata pelajaran normatif berhubungan dengan norma- norma yang ada disekitar, sedangkan mata pelajaran adaptif berhubungan dengan pengetahuan yang menunjang pelajaran produktif. Penelitian akan diadakan di SMK karena disana fisika merupakan mata pelajaran adaptif. Mata pelajaran adaptif yang lebih menekankan pada penguasaan konsep yang melandasi kompetensi untuk bekerja sesuai dengan jurusan yang dipilih. Fisika yang bukan mata pelajaran produktif atau normatif menyebabkan fisika kurang mendapat perhatian dari peserta didik. Namun, karena adanya praktikum virtual dengan menggunakan laboratorium virtual berbasis website ini peserta didik dapat memperoleh pengetahuan dari praktikum fisika dengan cara yang mereka sukai.

SMK Negeri 3 memiliki beberapa jurusan, salah satunya Teknik Komputer dan Jaringan (TKJ). Dimana peserta didik di jurusan tersebut tidak pernah lepas dari komputer. Sekolah ini memiliki ruangan laboratorium komputer yang memadai dengan lebih kurang 120 perangkat komputer dan 6 server utama. Selain memiliki banyak perangkat komputer tersebut, sekolah ini juga memiliki akses jaringan internet sendiri. Meskipun memiliki laboratorium komputer yang memadai, namun sekolah ini tidak memiliki laboratorium sains termasuk fisika. Hal ini mengakibatkan tidak dapat terlaksananya praktikum fisika dalam proses pembelajaran. Karena alasan tersebut dirasa laboratorium virtual berbasis website perlu diteliti di sekolah ini.

Penelitian yang relevan adalah penelitian dengan judul "Pengembangan Media Pembelajaran Laboratorium Virtual untuk Mengatasi Miskonsepsi Pada Materi Fisika Inti di SMAN 1 Binamu, Jeneponto"(7). Perbedaanya terletak pada media website yang digunakan. Pada penelitian relevan menggunakan aplikasi yang diakses secara offline, sedangkan pada penelitian ini menghasilkan website yang diakses secara online.

Oleh karena itu perlu di lakukannya penelitian yang berjudul "Pengembangan Laboratorium Virtual Berbasis Website di Kelas X Teknik Komputer dan Jaringan (TKJ)". Untuk mendeskripsikan pengembangan dan kelayakan media laboratorium virtual berbasis website. Adapun rumusan masalah dalam penelitian ini adalah (1) Bagaimana pengembangan media laboratorium fisika virtual berbasis website di kelas X Teknik Komputer dan Jaringan (TKJ) SMKN 3 Kota Bengkulu (2) Bagaimana kelayakan media laboratorium fisika virtual berbasis website di kelas X Teknik Komputer dan Jaringan (TKJ) SMKN 3 Kota Bengkulu.

\section{METODELOGI PENELITIAN}

Model pengembangan 4-D (Four D) adalah model yang dikembangkan oleh S. Thiagarajan, Dorothy S. Semmel, dan Melvyn I Semmel terdiri dari beberapa tahapan, yaitu tahap pendefinisian (define), tahap perancangan (design), tahap pengembangan (develop), tahap penyebaran (disseminate). Tujuan lain dari tahap ini adalah untuk menguji efektivitas penggunaan perangkat dalam kegiatan pembelajaran. Jenis penelitian ini adalah penelitian dan pengembangan research and development (R\&D). Penelitian ini beorientasi terhadap pengembangan produk. Produk yang dimaksudkan adalah media pembelajaran laboratorium virtual berbasis website (12). 
Populasi dalam penelitian ini yaitu peserta didik kelas X Teknik Komputer dan Jaringan (TKJ) SMK Negeri 3 Kota Bengkulu. Teknik pegumpulan data yang digunakan adalah menggunakan angket. Data yang di dapat dari angket yaitu validasi tim ahli.

Sebelum media laboratorium virtual berbasis website diberikan kepada peserta didik, dirasa perlu adanya penilaian kelayakan media dari ahli. Penilaian ini dilakukan dengan bantuan instrumen penelitian berupa angket. Angket berfungsi sebagai pengukur indikator media pembelajaran dalam hal tampilan media website, kualitas media website, kemudahan pengoperasian media untuk menilai keberhasilan media ini. Angket ditujukan kepada ahli media sebagai validasi media (construct validity) yang terdiri dosen pembimbing dan guru fisika.

Angket berisi penilaian dalam segi aspek format, aspek ilustrasi, aspek bahasa, dan aspek isi. Aspek format memiliki indikator penilaian yaitu, tiap bagian dapat diidentifikasi dengan jelas, sistem urutan kegiatan jelas, pengaturan tata letak yang jelas, jenis font dan ukuran font yang sesuai. Aspek ilustrasi memiliki indikator penilaian yaitu, ilustrasi mudah untuk dipahami, tampilan ilustrasi jelas, ilustrasi sesuai dapat memperjelas kegiatan yang dilakukan. Aspek bahasa memiliki indikator penilaian yaitu, tata bahasa yang benar sesuai dengan EYD, kalimat yang digunakan sederhana sesuai dengan tingkatan sekolah, petunjuk penggunaan yang jelas, bahasa yang digunakan komunikatif. Aspek isi memiliki indikator penilaian yaitu, materi yang disajikan benar sesuai dengan Silabus, dikelompokkan sesuai dengan peta konsep materi, sesuai dengan praktikum riil.

Analisis data dilakukan secara kualitatif untuk mengetahui kelayakan dari pengembangan laboratorium virtual berbasis website. Untuk menerjemahkan angket tersebut ke dalam bentuk data kualitatif maka skala yang digunakan adalah skala likert. Skala likert untuk mengukur tingkat kelayakan suatu alat. Dengan skala likert, maka variable yang akan diukur dijabarkan menjadi indicator variabel. Kemudian indikator tersebut dijadikan sebagai tolak untuk menyusun item-item yang dapat berupa pertanyaan maupun pernyataan (13).

Skala likert yang digunakan untuk melihat tingkat validitas suatu produk dalam penelitian dan pengembangan ini dimodifikasi dari skala likert berjumlah 5 skala menjadi 4 skala, yaitu terlihat pada Tabel 1.

Tabel 1. Interpretasi Skala Likert

\begin{tabular}{lc}
\hline \multicolumn{1}{c}{ Interpretasi } & Skor \\
\hline Sangat Baik (SB) & 4 \\
Baik (B) & 3 \\
Tidak Baik ( TB) & 2 \\
Sangat Tidak Baik (STB) & 1 \\
\hline
\end{tabular}

dengan adanya tabel di atas tersebut, peneliti dapat melihat skor interpretasi sesuai dengan Skla likert.

Modifikasi terhadap skala likert dimaksudkan untuk menghilangkan kelemahan yang terkandung oleh skala lima tingkat, dengan alasan yang dikemukakan seperti: 1) Kategori undeciden itu mempunyai arti ganda, bisa diartikan belum dapat memutuskan atau memberi jawaban (menurut konsep ahlinya), bisa juga diartikan netral, setuju tidak, tidak setuju pun tidak, atau bahkan ragu-ragu, 2) Tersedianya jawaban yang ditengah itu menimbulkan jawaban ke tengah (central tendency effect), terutama bagi mereka yang ragu-ragu atas arah kecendrungan pendapat responden, ke arah setuju atau ke arah tidak setuju (14).

Skala ini digunakan untuk mengukur tingkat validasi website untuk mengetahui apakah media yang dikembangkan layak digunakan para pendidik dan peserta didik yang dirancang termasuk kategori baik atau tidak.

Untuk menentukan persentase nilai validasi menggunakan rumus :

$$
\text { Validasi }(V)=\frac{\text { skor total }}{\text { Total skor ideal skor maksimal }} \times 100 \%
$$

Hasil yang telah diketahui persentasenya dapat dicocokkan dengan kriteria yang dapat dilihat pada Tabel 2 Modul yang dikembangkan dapat dikatakan baik/layak apabila memenuhi kriteria dengan persentase $\geq 51 \%$.

Pengembangan Laboratorium Virtual Berbasis Website di Kelas X Teknik Komputer dan Jaringan (TKJ)

Dara Riska, Afrizal Mayub, Rosane Medriati 


\begin{tabular}{ll}
\hline \multicolumn{2}{|c}{ Tabel 2. Kriteria Hasil Validitas } \\
\hline $1,00 \%-50,00 \%$ & Interpretasi \\
$50,01 \%-70,00 \%$ & Tidak layak (terlarang digunakan) \\
$70,01 \%-85,00 \%$ & Cukup layak (tidak dapat digunakan) \\
$85,01 \%-100 \%$ & Sangat layak (dapat digunakan dengan revisi kecil) \\
\hline
\end{tabular}

(Adaptasi dari Kurniasari dan Qohar (15))

dengan adanya Tabel 2 tersebut, peneliti dapat melihat presentase untuk melihat kriteria hasil validasi yang di peroleh.

\section{Hasil dan Pembahasan}

\subsection{Hasil Penelitian}

Penelitian ini telah menghasilkan produk berupa website pada materi suhu dan kalor di kelas X TKJ 2 SMK Negeri 3 Kota Bengkulu. Produk ini dinyatakan sangat valid berdasarkan penilaian oleh tim ahli yaitu validator sebanyak 3 orang. Penelitian ini tidak sempurna dikarenakan adanyan pandemi COVID-19 yang melanda Indonesia, termasuk Kota Bengkulu. Sehingga penelitian hanya dilakukan sebatas uji validasi.

Produk website yang telah dikembangkan dalam penelitian ini disusun berdasarkan model pengembangan 4D, namun hanya digunakan 3 tahapan dikarenakan waktu dan biaya yang terbatas untuk dilakukannya tahap penyebaran. Tiga tahapan itu adalah tahap pendefinisian (define), tahap perancangan (design), dan tahap pengembangan (develope). Tahapan-tahapan yang telah dilakukan adalah sebagai berikut.

\subsubsection{Tahap Pendefinisian (Define)}

Pada tahap pendefinisian, telah disusun hal-hal yang dibutuhkan dalam proses pembelajaran dengan cara menganalisis tujuan dan batasan pada materi suhu dan kalor. Tahap ini terdiri dari lima tingkat tahapan, yaitu:

1) Analisis awal

Pada tahapan analisis awal telah dilakukan identifikasi masalah dasar yang ada disekolah melalui observasi. Berdasarkan hasil pengamatan yang dilakukan dengan cara observasi di SMK 3 Bengkulu, diketahui bahwa terdapat banyak kendala untuk melakukan kegiatan praktikum.

Diantaranya adalah tidak adanya laboratorium fisika, keterbatasan waktu guru untuk mempersiapkan dan melaksanakan praktikum, keterbatasan pengadaan peralatan laboratorium, konsep fisika yang tidak semuanya dapat dipraktikumkan.

Di SMKN.3 tidak terdapat laboratorium untuk mata pelajaran adaptif seperti fisika,dll. Di sekolah ini hanya terdapat laboratorium penunjang untuk mata pelajaran produktif, seperti laboratorium komputer, dapur tata boga, klinik kecantikan, butik busana, dll.

Terbatasnya waktu guru untuk mempersiapkan praktikum juga menjadi perhatian, karena pelajaran fisika di kelas X TKJ 2 ini hanya 3 jam pelajaran perminggunya. Pengadaan alat laboratorium yang tidak lengkap di sekolah ini juga menjadi perhatian. Hanya ada alat-alat sederhana seperti jangka sorong, neraca, thermometer, dan alat-alat sederhana lainnya. Sedangkan alat yang cukup rumit seperti musschenbroek / alat ukur muai panjang dan alat praktikum rumit lainnya tidak ada di sekolah ini.

Peserta didik yang diteliti adalah peserta didik kelas X TKJ 2, dimana peserta didik tidak pernah lepas dari komputer. Praktik komputer pada mata pelajaran kejuruan (produktif) tersebut membuat peserta didik di sekolah ini cenderung lebih bersemangat dalam mengikuti pelajaran kejuruan dibandingkan dengan mata pelajaran lain terutama fisika.

2) Analisis Peserta Didik

Peserta didik di kelas X TKJ 2 SMKN 3 Kota Bengkulu rata-rata berusia 15-16 tahun dan sudah masuk pada masa remaja awal. Pada masa ini remaja memasuki tahap operasi formal atau tahap dimana usia peserta didik telah dapat berfikir secara abstrak (16). Kemampuan akademik peserta didik di kelas X TKJ 2 SMKN 3 Kota Bengkulu dengan mata pelajaran fisika bersifat heterogen, dan dibagi menjadi 3 yaitu bekemampuan tinggi, berkemampuan sedang, dan berkemampuan 
rendah. Penilaian tersebut berdasarkan nilai ujian harian $\mathrm{BAB}$ sebelumnya yang telah diberikan oleh guru fisika seperti terlihat pada Gambar 1.

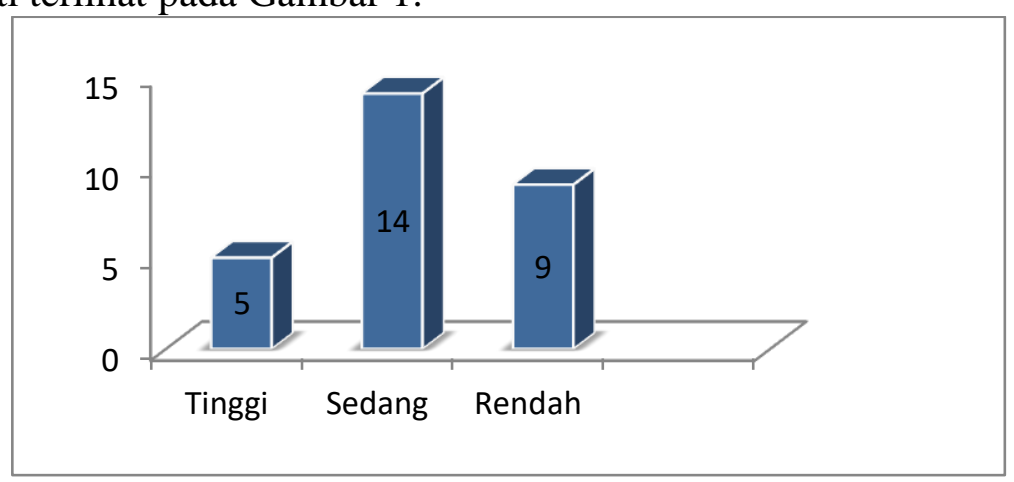

Gambar 1 Grafik kategori kemampuan akademik peserta didik

dengan adanya tabel di atas tersebut, peneliti dapat melihat kategori kemampuan peserta didik.

3) Analisis Tugas

Pada tahap analisis tugas ini dilakukan penyusunan tugas yang akan diselesaikan oleh peserta didik untuk mencapai kompetensi dasar sesuai dengan ketentuan Kurikulum 2013 KIKD 2017. Tugas tersebut berupa evaluasi peserta didik setelah melakukan praktikum virtual di website mengenai materi suhu dan kalor sesuai dengan tujuan pembelajrannya.

4) Analisis Konsep

Tahap konsep ini telah dilakukan dengan cara mengidentifikasi materi pelajaran tentang suhu dan kalor, serta menyusunnya secara sistematis untuk dipelajari oleh peserta didik. Setelah disusun sesuai dengan ketentuan Kurikulum 2013 KIKD 2017 maka materi pelajaran yang dibahas pada penelitian ini adalah materi tentang suhu, pemuaian, kalor, serta perpindahan kalor. Semua materi dipersiapkan untuk dimasukkan ke halaman website.

5) Tujuan Pembelajaran

Tujuan pembelajaran disusun berdasarkan kompetensi dasar 3.6 dan 4.6 sebagaimana yang sesuai dengan ketentuan Kurikulum 2013 KIKD 2017. Berikut merupakan tujuan yang harus dicapai dalam pembelajaran suhu dan kalor pada peserta didik kelas X TKJ 2 SMKN 3 Kota Bengkulu :

\subsubsection{Tahap Perancangan (Design)}

Pada tahap perancangan ini bertujuan untuk menghasilkan rancangan produk berupa laboratorium virtual berbasis website yang akan dikembangkan. Langkah- langkah ini dilakukan dengan cara menyusun instrument atau perangkat pemebelajaran, pemilihan media yang sesuai, pemilihan format, serta rancangan awal. Langkah-langkah tersebut dijelaskan secara rinci dibawah ini :

1) Penyusunan instrument

Pada tahap ini akan dirancang tes acuan patokan yang disusun berdasarkan analisis tugas dan analisis konsep. Tes yang dimaksud adalah tes hasil belajar pokok bahasan suhu dan kalor yang berupa pre test dan post tes saat melakukan kegiatan praktikum virtual. Pre test dilakukan pada saat sebelum melakukan praktikum. Sedangkan post test dilakukan setelah dilakukannya praktikum.

2) Pemilihan Media

Tahap pemilihan media ini dipilih beberapa media yang tepat untuk digunakan dalam pengembangan produk ini. Media yang dipilih adalah website yaitu media online. Kemudian computer atau Personal Computer (PC) untuk menampilkan visual website, serta jaringan internet untuk mengakses website.

\section{3) Pemilihan Format}

Format yang digunakan dalam penelitian ini berupa HTML atau website. Website merupakan berkas yang ditulis sebagai berkas teks biasa (plain text) yang diatur dan dikombinasikan dengan instruksi- instruksi berbasis HTML. Berkas tersebut kemudian diterjemahkan oleh browser dan ditampilkan seperti layaknya sebuah halaman pada monitor komputer.

4) Rancangan Awal 
Tahap rancangan awal merupakan tahap yang diperoleh dari analisis awal hingga pemilihan format yang tepat untuk menghasilkan produk akhir. Produk akhir yang dihasilkan adalah website. Website yang digunakan adalah website dari WordPress. WordPress adalah platform pembuatan website yang diciptakan oleh Matt Mullenweg dan Mike Little (17). Adapun rancangan awal dari produk ini yaitu terdiri beranda/ home, biodata pembuat website, materi suhu dan kalor, peta konsep suhu dan kalor, link yang menuju ke arah laboratorium virtual, video pembelajaran percobaan virtual suhu dan kalor, dan contoh soal suhu dan kalor. Selain itu, juga terdapat artikel-artikel tentang fisika secara umum. Alamat website ini adalah https://sains.1001tutorial.com/. Berikut tampilan awal website.

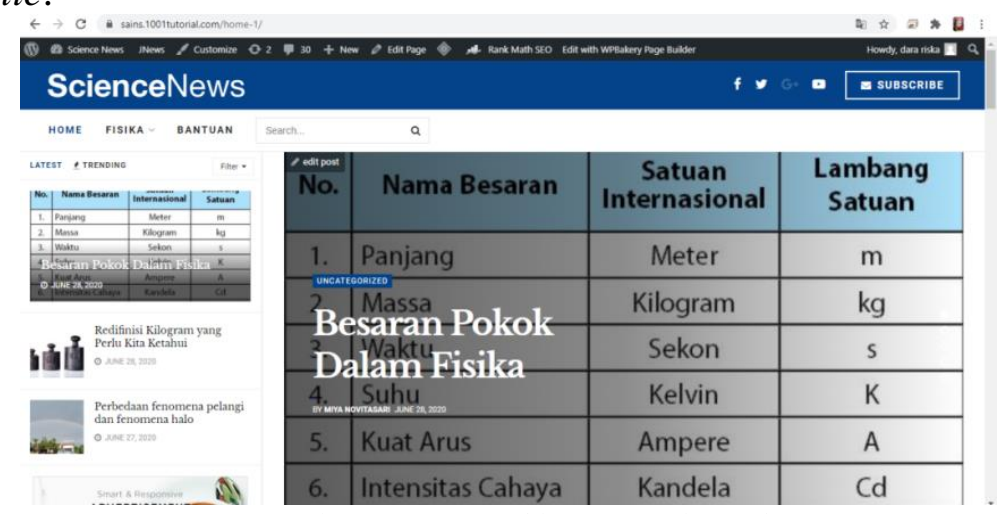

Gambar 2, Tampilan awal website

Gambar 2 menunjukkan bagaimana laman tampilan awal dari website yang dibuat peneliti.

\subsubsection{Tahap Pengembangan (Develope)}

Tahap pengembangan merupakan penilaian terhadap media pembelajaran praktikum fisika virtual berbasis Website oleh para ahli dan uji coba lapangan. Adapun tahapan dalam tahap pengembangan adalah sebagai berikut.

1) Validasi Ahli/Logic

Setelah melewati tahap pendefinisian dan tahap perancangan, maka tahap selanjutnya adalah tahap validasi. Aspek yang dinilai dari tahap validasi adalah aspek format, aspek indicator, aspek bahasa, serta aspek isi. Data yang didapatkan dari validator digunakan sebagai dasar dalam melakukan revisi, sehingga media pembelajaran praktikum fisika virtual berbasis Website dapat digunakan pada tahap uji pengembangan.

Hasil dari penilaian validator terhadap produk yang dikembangkan kemudian dihitung persentasenya $(\%)$ dengan cara menjumlahkan skor total responden $\left(\sum \mathrm{x}\right)$ per aspek dibagi dengan jumlah skor ideal / skor maksimal ( $\sum \mathrm{xi}$ ) per aspek, dan dikali dengan $100 \%$. Untuk persentase ratarata didapatkan dari menjumlahkan total persentase per aspek, dibagi dengan jumlah banyaknya aspek.

Setelah didapatkan persentase rata-rata, bias diperoleh kriteria apa interperensi yang telah dilakukan. Penilaian uji validasi yang telah dilakukan oleh validator disajikan dalam Tabel 3.

Tabel 3. Hasil Validasi Ahli

\begin{tabular}{ccccc}
\hline Aspek & $\begin{array}{c}\text { Jumlah jawaban per } \\
\text { aspek }\left(\sum \mathrm{x}\right)\end{array}$ & $\begin{array}{c}\text { Jumlah nilai ideal } \\
\text { per aspek }\left(\sum \mathrm{x}\right)\end{array}$ & $\begin{array}{c}\text { Persentase per } \\
\text { aspek }(\mathrm{P})\end{array}$ & Kriteria \\
\hline Format & 41 & 48 & 85,41 & Sangat Layak \\
Ilustrasi & 31 & 36 & 86,11 & Sangat Layak \\
Bahasa & 41 & 48 & 85,42 & Sangat Layak \\
Isi & 33 & 36 & 91,67 & Sangat Layak
\end{tabular}

Persentase

rata-rata

87,15

Kriteria

Sangat Layak

Tabel 3 menunjukkan bagaimana hasil validasi tim ahli dari produk yang dibuat peneliti.

Berdasarkan tabel 3, diperoleh bahwa nilai persentase rata-rata dari seluruh aspek adalah 87,15\% dengan kriteria penilaian sangat layak dan dengan total penilaian 146. Adapun rincian persentasenya yaitu : jumlah persentase validasi pada aspek format adalah $85,41 \%$ kriteria sangat 
layak : jumlah persentase validasi pada aspek ilustrasi adalah $86,11 \%$ kriteria sangat layak ; jumlah persentase validasi pada aspek bahasa adalah $41 \%$ kriteria sangat layak ; dan jumlah persentase validasi aspek isi adalah 91,67\% dengan kriteria sangat layak. Saran dan masukan validator menjadi dasar untuk merevisi produk ini menjadi lebih baik.

2) Revisi

Berdasarkan hasil dari validasi yang dilakukan oleh validator, maka didapatkan masukan dan saran yang menjadi dasar untuk melakukan revisi pengembangan produk. Tabel 4 berikut merupakan saran dan masukan yang diberikan oleh validator terhadap laboratorium virtual berbasis website yang dikembangkan.

Tabel 4. Masukan dan Saran Tim Ahli

\begin{tabular}{|c|c|c|c|}
\hline No. & Aspek & Saran / Masukan & Hasil Perbaikan \\
\hline 1. & Format & $\begin{array}{l}\text { - Harus kembali ke menu atas untuk } \\
\text { memilih menu yang lain }\end{array}$ & $\begin{array}{l}\text { - Tambahkan tombol back dan } \\
\text { next }\end{array}$ \\
\hline 2. & Ilustrasi & $\begin{array}{l}\text { - Ada tampilan laboratorium virtual } \\
\text { yang tidak dapat terkoneksi }\end{array}$ & $\begin{array}{ll}\text { - } & \text { Tambahkan } \\
\text { bantuan/help } & \text { tombol }\end{array}$ \\
\hline 3. & Bahasa & Petunjuk lebih diperinci & $\begin{array}{l}\text { - Memperjelas kalimat dan } \\
\text { memberikan keterangan } \\
\text { gambar agar lebih mudah } \\
\text { dipahami peserta didik }\end{array}$ \\
\hline \multirow[t]{2}{*}{4.} & \multirow[t]{2}{*}{ Isi } & $\begin{array}{l}\text { - Menjawab contoh soal secara } \\
\text { langsung di website }\end{array}$ & $\begin{array}{l}\text { - Melampirkan google form } \\
\text { agar peserta didik dapat } \\
\text { langsung mengerjakan soal di } \\
\text { web }\end{array}$ \\
\hline & & $\begin{array}{l}\text { - Video pembelajaran } \\
\text { memiliki background asli }\end{array}$ & $\begin{array}{l}\text { - Menghilangkan background } \\
\text { asli pada video pembelajaran }\end{array}$ \\
\hline
\end{tabular}

Tabel 4 memperlihatkan bagaimana saran dan masukan hasil validasi tim ahli beserta hasil perbaikan sudah dibuat peneliti.

\subsection{Pembahasan Hasil Penelitian}

Metode yang digunakan dalam penelitian ini yaitu research and development (R\&D) yang merupakan penelitian dan pengembangan dengan model 4D yang telah diadaptasi menjadi tiga yaitu define, design, dan develope.

Tahap pertama yang dilakukan dalam penelitian ini adalah tahap pendefinisian atau define, dimana pada tahap ini memiliki tujuan mengkaji media pembelajaran yang dikembangkan yaitu praktikum virtual berbasis website. Setelah mengkaji media pembelajaran yang akan dikembangkan, dilanjutkan dengan tahapan perancangan atau design media pembelajaran. Rancangan laboratorium virtual berbasis website telah disesuaikan dengan kompetensi dasar dan indikator yang tercantum di dalam kurikulum 2013. Website telah memuat beranda, biodata pembuat, kata pengantar, peta konsep, materi, contoh soal, serta praktikum virtual dengan materi suhu dan kalor. Setelah mendapatkan hasil dari perancangan, maka yang harus dilakukan selanjutnya yaitu pengembangan atau develop.

Tahap ketiga atau tahap terakhir dari pembuatan produk ini adalah pengembangan atau develop. Pada tahap ini dilakukan validasi yang dilakukan oleh tim ahli yang berjumlah 3 orang yang terdiri dari 2 tim ahli dari Universitas Bengkulu dan 1 tim ahli dari guru fisika SMK Negeri 3 Kota Bengkulu.langkah-langkah untuk menganalisis kesulitan yaitu ; pertama, persentase aspek penilaian kevalidan media dihitung. Selanjutnya, persentase penilaian media per aspek yang telah dihitung sebelumnya dan diterjemahkan secara kualitatif dengan kriteria interpretasi yang telah ditentukan (lihat tabel 1). Cara menghitung rata-rata persentase secara keseluruhan, yaitu dengan cara membagi persentase per aspek dengan jumlah aspek penilaian.

Berdasarkan data hasil validasi maka media pembelajaran yang dikembangkan dikategorikan sangat layak karena aspek-aspek penilaian dari media pembelajaran yang dikembangkan menunjukkan nilai rata-rata persentase sebesar $87,5 \%$ dengan kriteria interprestasi penilaian yaitu sangat layak. Semua aspek penilaian terhadap media yang dikembangkan menunjukkan kriteria 
yang sangat layak untuk digunakan. Namun ada beberapa masukan dan saran dari validator setelah dilakukan validasi. Revisi perlu dilakukan sesuai dengan masukan dan saran dari validator yang telah diberikan. Masukkan dan saran dari validator yang Perlu diperbaiki dalam laboratorium virtual berbasis website yang dikembangkan yaitu, 1) Tambahkan tombol back dan next, 2) Mengatasi tampilan yang tidak dapat terkoneksi, 3) bahasa dalam petunjuk lebih diperinci, 4) contoh soal dijawab langsung pada halaman website, 5) Hapus background asli video pembelajaran.

Penelitian yang relevan dalam penelitian ini adalah penelitian dengan judul "Pengembangan Media Pembelajaran Laboratorium Virtual untuk Mengatasi Miskonsepsi Pada Materi Fisika Inti di SMAN 1 Binamu, Jeneponto" memiliki kemiripan berupa hasil kelayakan media dinyatakan sudah layak untuk digunakan terhadap peserta didik. Di dalam produk yang dibuat selain sama-sama terdapat laboratorium virtual juga terdapat peramgkat pembelajaran seperti RPP dan LKPD. Kriteria penilaian kelayakan produk pada penelitian yang relevan diatas adalah sangat layak dengan persentase kelayakan $93,03 \%$ dan pada penelitian ini kriteria penilaian kelayakan produk adalah sangat layak dengan persentase kelayakan $87,15 \%$ (7).

\section{Kesimpulan dan Saran}

\subsection{Kesimpulan}

Berdasarkan hasil pengembangan yang telah dikemukakan pada bab sebelumnya dapat disimpulkan pengembangan laboratorium virtual dikembangkan melalui tahapan pendefinisian (define), yaitu tahap analisis awal, analisis peserta didik, analisis tugas, analisis konsep, dan spesifikasi tujuan pembelajaran. Tahap perancangan (design) melalui tahapan penyusunan instrument, media, format, dan menghasilkan rancangan awal. Serta tahap pengembangan (develope) yang merupakan tahapan uji validitas ahli.

Laboratorium virtual berbasis website dengan materi suhu dan kalor berdasarkan uji validitas ahli dinyatakan sangat layak untuk digunakan. Berdasarkan penilaian laboratorium virtual berbasis website didapatkan nilai rata-rata persentase sebesar $87,5 \%$ dengan kriteria interprestasinya yaitu sangat layak. Hal ini menunjukkan bahwa laboratorium virtual berbasis website yang dikembangkan sudah sangat layak digunakan oleh peserta didik untuk menunjang pembelajaran di sekolah.

\subsection{Saran}

Saran dari penelitian ini yaitu, hasil pengembangan media pembelajaran berupa laboratorium virtual berbasis website pada materi suhu dan kalor diharapkan dapat digunakan dalam proses pembelajaran di sekolah, terutama di SMKN 3 Kota Bengkulu mengingat permasalahan yang ada di sekolah, sehingga laboratorium virtual berbasis website yang telah dikembangkan menjadi lebih bermanfaat. Penelitian ini merupakan penelitia pengembangan media pembelajaran, sehingga menghasilkan perangkat media pembelajaran yang dapat digunakan untuk menunjang proses pembelajaran. Oleh karena itu diharapkan setelah dilakukan revisi produk, sebaiknya penelitian ini tetap diteruskan untuk melihat respon peserta didik terhadap media yang telah dihasilkan. Dalam penulisan skripsi banyak memiliki kekurangan dikarenakan adanya wabah COVID-19. Diharapkan setelah wabah ini berlalu, penelitian ini dapat dilanjutkan dan diperbaiki kembali.

\section{UCAPAN TERIMAKASIH}

Penulis mengucapkan terimakasih kepada validator ahli yaitu Andik Purwanto, M.Si dan Eko Risdianto, M.Cs serta Desfina Qodriyah, M.TPd (guru di SMKN 3 Kota Bengkulu) yang sudah bersedia untuk membatu menilai kelayakan produk laboratorium virtual berbasis website.

\section{DAFTAR PUSTAKA}

1. Suparwoto. Peran Pendidikan Fisika dalam Pengembangan Budaya. Yogyakarta: Publisher UNY; 2005.

2. Kemendikbud. Dokumen Kurikulum 2013. Jakarta: Kementrian Pendidikan dan Kebudayaan; 2012. 1 p.

3. Mundilarto. Penilaian Hasil Belajar Fisika. Yogyakarta: P2IS UNY; 2012. 
4. Hamalik O. No Title. Bandung: PT Alumni; 1986. 30-31 p.

5. Depdiknas. Pendekatan Kontekstual. Jakarta: Depdiknas; 2002.

6. Arsyad A. Media Pembelajaran. Jakarta: PT. Raja Grafindo Persada; 2013. 38-39 p.

7. Swandi A, Hidayah S, Irsan. Pengembangan Media Pembelajaran Laboratorium Virtual untuk Mengatasi Miskonsepsi Pada Materi Fisika Inti di SMAN 1 Binamu, Jeneponto. J Fis Indones. 2014;XVIII(April):20-4.

8. Nafrianti N, Supardi I, Erman. Pengembangan Perangkat Pembelajaran Inkuiri Terbimbing Berbantuan PhET pada Materi Listrik Dinamis untuk Meningkatkan Keterampilan Berpikir Kritis Siswa. J Penelit Pendiidkan Sains. 2016;

9. Djamarah, Zain. Strategi Belajar Mengajar. Jakarta: Rineka Cipta; 2006.

10. Darmadi, Suharyanto. Pengembangan Website Dilengkapi Virtual Lab PhET Sebagai Media Meningkatkan Pemahaman Konsep Listrik Dinamis Pada Pembelajaran Fisika. UNY. 2015;

11. Kusumaningsih Y., Iswahyudi, Susanti E. Pengembangan Model Laboratorium Virtual sebagai Solusi Keterbatasan Sumber Daya Pembelajaran. Pros Semin Nas Apl Sains Teknol (SNAST) ST AKPRIND. 2014;

12. Rizal A, Adam RI, Susilawati. No Title. Pengemb Lab Virtual Fis Osilas. 2018;

13. Sugiyono. Metode Penelitian Pendidikan. Bandung: Alfabeta; 2010.

14. Hertanto E. Perbedaan Skala Likert Lima Skala dengan Modifikasi Skala Likert Empat Skala. Jakarta: Jurnal Metologi Penelitian September 2017; 2017.

15. Ferrina Dwi Kurniasari, Qohar A. PENGEMBANGAN MEDIA PEMBELAJARAN MATEMATIKA BERBANTUAN KOMPUTER PADA MATERI RUANG DIMENSI TIGA UNTUK SISWA KELAS X SMA BILINGUAL. J Univeristas Negeri Malang [Internet]. 2013;1-10. Available from: https://docplayer.info/151957-Pengembangan-mediapembelajaran-matematika-berbantuan-komputer-pada-materi-ruang-dimensi-tiga-untuksiswa-kelas-x-sma-bilingual.html

16. Sugihartono. Psikologi Pendidikan. Yogyakarta: UNY Press; 2012.

17. Nilasari S. Jago Membuat Website Gratis \& Cepat Secara Otodidak. Jakarta: Dunia Komputer; 2014. 